\title{
Trademarks from the Government Viewpoint
}

\author{
Daphne Leeds*
}

The free enterprise system, which has made ours a nation industrially strong, envisages free competition-fair as distinguished from unfairproviding free choice between like products in the markets. Trademarksbrand names, symbols, slogans and devices-foster freedom of competition and facilitate freedom of choice, and in so doing, they assume a stature of considerable economic and social importance. Identity of product is essential to the creation and development of a market, and the trademark is the means to this end. It was undoubtedly this consideration which led Congress to enact legislation for the protection of these marks of identity.

The congressional committees in their reports recommending the legislation put it this way: ${ }^{1}$

Trademarks, indeed, are the essence of competition, because they make possible a choice between competing articles by enabling the buyer to distinguish one from the other. Trademarks encourage the maintenance of quality by securing to the producer the benefit of the good reputation which excellence creates. To protect trademarks, therefore, is to protect the public from deceit, to foster fair competition, and to secure to the business community the advantages of reputation and goodwill by preventing their diversion from those who have created them to those who have not.

The Patent Office of the Umited States was first authorized in 1881 to register trademarks used on products moving in the channels of interstate trade; and the authority has remamed in that agency in successive acts of Congress, ${ }^{2}$ including that of July 5, 1946 (Lanham Act), ${ }^{3}$ with the administration of which the Office is presently charged. The legislative history of the statute states and restates five basic purposes to be accomplished, three of which will be discussed in this paper. They are: ${ }^{4}$

1. To modernize the trademark statutes so that they will conform to legitimate present-day business practices.

2. To remedy constructions of the present acts which have in sev-

*Assistant Commissioner, United States Patent Office, Washington, D.C.

1 H.R. REP. No. 219, 79th Cong., 1st Sess. 3 (1945) ; S. REP. No. 1358, 79th Cong., $2 d$ Sess. 4 (1946).

233 StaT. 724 (1905), as amended, 15 U.S.C. $\$ \S 81,85,94,121,133$ (1952), 31 U.S.C. § 687 (1952).

360 StaT. 427 (1946), 15 U.S.C. $\S \S 1051-127$ (1952), as amended, 68 StaT. 509 (1954).

4 H.R. Rep. No. 219, 79th Cong., 1st Sess. (1945); S. Rep. No. 1358, 79th Cong., 2d Sess. (1946). 
eral instances obscured and perverted their original purpose. These constructions have become so ingrained that the only way to change them is by legislation.

3. Generally to simplify trademark practice, to secure trademark owners in the goodwill which they have built up, and to protect the public from imposition by the use of counterfeit and imitated marks and false trade descriptions.

\section{MODERNIZATION OF TRADEMARK STATUTES}

In the forty-one year period between 1905 and 1946 business practices had undergone a considerable change. Congress recognized that a change had taken place and included provisions which made possible similar recognition by the Patent Office in its administration of the law. The provisions reflecting substantive changes will be treated here in five major categories: (1) registration by related companies, (2) registrability of secondary meaning marks, (3) registrations based on concurrent lawful use, (4) registrability of service, collective and certification marks, and (5) assignment of part of a business.

\section{Registration by Related Companies}

It hardly needs to be pointed out that fifty years ago the American business community had a relatively simple structure. With the constant expansion of industry, however, the structure became more complex. Holding companies, parent-subsidiary relationships, corporate affiliates, and independent operations producing under a quality control exercised by another became more or less commonplace. These were the natural results of distribution expanded to a national scale. The framers of the Trademark Act of 1905 could not have foreseen this development, and therefore made no provision in the law either for registration or protection of marks used under such circumstances of relationship.

It is true that some courts ${ }^{5}$ extended protection to marks used by "related companies," but they did so under their broad powers of equity rather than under the trademark law, and many trademark owners experienced an uneasiness when they permitted others to use their marks even under conditions of complete control because of the ever-present danger of having their mark invalidated.

Whatever question may have existed as to registrability by a holding company or parent company of a mark used only by subsidiaries or affili-

5 Finchley, Inc. v. George Hess Co., 24 F. Supp. 94 (E.D.N.Y. 1938) ; H. Freeman \& Son, Inc. v. F. C. Huyck \& Son, Inc., 7 F. Supp. 971 (N.D.N.Y. 1934) ; Keebler Weyl Baking Co. v. J. S. Ivins' Son, Inc., 7 F. Supp. 211 (E.D. Pa. 1934) ; Coca-Cola Co. v. J. G. Butler \& Sons, 229 Fed. 224 (E.D. Ark. 1916); Dewees v. Schneider, 35 U.S.P.Q. 27 (Pa. Com. Pleas 1937). 
ates was put to rest when the Assistant Commissioner held that a holding company whose subsidiary used the mark for which registration was sought did not acquire rights sufficient to entitle it to register the mark. ${ }^{6}$ It was fourteen years later that Congress acted to provide something realistic in the statute. Thus, section 5 of the Lanham Act provides:7

Where a registered mark or a mark sought to be registered is or may be used legitimately by related companies, such use shall inure to the benefit of the registrant or apphicant for registration, and such use shall not affect the validity of such mark or of its registration, provided such mark is not used in such manner as to deceive the public.

"Related company" is defined as "any person who legitimately controls or is controlled by the registrant or applicant for registration in respect of the nature and quality of the goods or services in connection with which the mark is used." 8

The rules promulgated by the Patent Office in $1947^{\circ}$ in connection with these statutory provisions provided that when the first use was by a related company and such use inures to the benefit of the applicant, the date of first use asserted should mclude a statement that such use was by the related company; and when the mark sought to be registered was used by one or more related companies, the applicant "must recite exceptions to the averment of the exclusive right to use the mark," stating the nature of the relationship and, if practicable, the names and addresses of the related companies. ${ }^{10}$

Experience with this section indicated the desirability of a reappraisal of the second portion of the rule. It seemed obvious that if the applicant itself was using the mark, it was the owner for purposes of registration, and it soon became apparent that the identification of the related users at the time of the application served no purpose, since their identity might, and frequently did, change from time to time. Furthermore, the impropriety of requiring a trademark owner to recite use by related companies as "exceptions to the averment of the exclusive right to use the inark" when, in fact, sucl use was for the benefit of the owner and in no wise affected his exclusive rights, became evident. These considerations led to a revision of the rule in the summer of 1955 .

Under the revised rules it is necessary to recite use by a related com-

B Ex parte United States Steel Corp., 23 U.S.P.Q. 145 (Comm'r 1934).

760 STAT. 429 (1946), 15 U.S.C. \& 1055 (1952).

860 STAT. 443 (1946), 15 U.S.C. $\$ 1127$ (1952).

9 Procedure in the Patent Office is governed by the Rules of Practice in Trade-Mark Cases. The original rules (July 5, 1947) were published in 37 C.F.R. $\$ \S 100.11-413$ (1949). These rules were revised in 1955 (effective Aug. 15, 1955) and appear in 37 C.F.R. § 2.1-189 (Supp. 1955).

1037 C.F.R. \& 100.78 (1949). 
pany only when the mark is not in fact being used by the applicant but is used only by another whose use inures to the applicant's benefit. ${ }^{11}$ The Patent Office may, of course, require such details concerning the nature of the relationship and such proofs as may be necessary and appropriate to show that the use actually is for the applicant's benefit and does not affect the validity of the mark. Once the requirement is satisfied, the application is treated as any other.

It can be safely said that in respect of controlled use of trademarks by others than the actual owners, business developed the practice, and the courts, when called upon to do so, protected the trademark owner's rights. Registration based upon use by a related company, however, was not available. Congress recognized the practice and made registration possible; and the rules of practice have been revised to provide an orderly method of procedure for obtaining registration.

In the ten years since passage of the act of $1946,{ }^{12}$ it has become a not uncommon business practice to enter into license agreements which may be outside the scope of the present law. No opinion can be expressed concerning the effect of some of these hicense agreements on the involved marks, but an expression of genuine fear that our American concept of trademarks and their protection may be undermined by over-extension of the practice seems not out of order.

\section{Registrability of Secondary Meaning Marks}

One of the real changes welcomed by industry with the coming into force of the Lanham Act was that which made it possible to register marks which originally were unregistrable by reason of the fact that they were surnames, geographical names or descriptive terms, but which had, through extensive use and advertising, come to identify the products of specific manufacturers. The act of $1905 \mathrm{had}$, in a sense, recognized the possibility that such names, words or terms could perform a trademark function, since it included a provision for registration of marks which had been exclusively used as trademarks by the applicant (or predecessors) for ten years next preceding February 20, 1905, even though they might have been in an otherwise unregistrable category. ${ }^{13}$ Here again, the courts gave protection to marks which had acquired a secondary meaning, but the Patent Office consistently refused to register them under the 1905 act.

Section 2 of the 1946 act $^{14}$ provides for registration of marks which have become distinctive of an applicant's goods. Unlike the so-called "ten-

1137 C.F.R. $\$ 2.38$ (Supp. 1955).

1260 STAT. 427 (1946), 15 U.S.C. $\$ \$ 1051-127$ (1952), as amended, 68 STAT. 509 (1954).

1333 StaT. 726 (1905), 15 U.S.C. $\$ 85$ (1952).

1460 StaT. 428 (1946), 15 U.S.C. \$ 1052 (1952). 
year proviso" of the act of 1905, under which only those marks which had been in exclusive use for ten years preceding the effective date of the statute, subsection $2(\mathfrak{f})^{15}$ of the present act makes registrable all marks which have become distinctive of the applicant's goods (acquired a secondary meaning), except those specifically prohibited by subsections (a), (b), (c) and (d)..$^{16}$ The subsection also establishes a procedure whereby the Commissioner may accept as prima facie evidence of distinctiveness proof of substantially exclusive and continuous use of the mark for the five years next preceding the filing of the application.

The rules of practice require an applicant seeking registration for a secondary meaning mark to allege in the application that the mark has become distinctive. ${ }^{17}$ Failure to make the allegation, however, does not mean that evidence concerning distinctiveness will not be considered. ${ }^{18}$ Ordinarily, the mere allegation of distinctiveness is not sufficient in the case of marks being registered for the first time, since the allegation is a conclusion of the applicant and probably is not the "proof" contemplated by the statute. ${ }^{19}$ Evidence of extent of use by showing volume of sales, advertising expenditures, advertising media and copies of typical advertisements of the mark are helpful in arriving at a determination as to whether or not the mark has acquired a secondary meaning, and favorable action on an application is always expedited if suclu showing accompanies the application rather than having the Office request it.

Secondary meaning, or distinctiveness, is always a fact question and must be resolved from the facts presented. Thus, descriptive inarks, ${ }^{20}$ surnames, ${ }^{21}$ and geographical names ${ }^{22}$ are registrable when the facts presented make a prima facie showing of distinctiveness. ${ }^{23} \mathrm{And}$, it slould be observed,

1560 STAT. 429 (1946), 15 U.S.C. \$1052 (f) (1952).

16 Bavarian Brewing Co. v. Heileman, 107 U.S.P.Q. 245, 46 TrademaRk Rep. 359 (Comm'r 1955).

1737 C.F.R. $\$ 2.41$ (Supp. 1955).

18 Mass-Rowe Electromusic Corp. v. Schulmerich Electronics, Inc., 108 U.S.P.Q. 289, 46 Trademark Rep. 490 (Comm'r 1956) ; Stromberg Carlson Co. v. Schulmerich Electronics, Inc., 108 U.S.P.Q. 286, 46 TradeMaRK REP. 491 (Comm'r 1956).

19 Minnesota Mining \& Mfg. Co. v. Minnesota Linseed Oil Paint Co., 43 C.C.P.A. (Patents) ......., 229 F.2d 448, 108 U.S.P.Q. 314 (1956).

${ }^{20}$ Ex parte Stowe-Woodward, Inc., 100 U.S.P.Q. 310, 44 TRADE-MaRK REP. 737 (Counun'r 1954); Ex parte Bemis Bro. Bag Co,, 100 U.S.P.Q. 194, 44 TRADE-MARK REP. 694 (Comm'r 1954); Ex parte James H. Forbes Tea \& Coffee Co., 100 U.S.P.Q. 164, 44 Trade-Mark Rep. 684 (Counn'r 1954); Ex parte The National Machinery Co,, 100 U.S.P.Q. 67, 44 TradE-Marz ReF. 597 (Coinm'r 1953) ; Ex parte Pillsbury Mills, Inc., 99 U.S.P.Q. 474, 44 Trade-MaRK REP. 459 (Comin'r 1953).

21 Ex parte Murray Corp. of America, 103 U.S.P.Q. 155, 45 TradE-MaRK REP. 225 (Coinm'r 1954).

22 Ex parte Oneida, Ltd., 102 U.S.P.Q. 122, 44 Trade-Mark REP. 1234 (Comm'r 1954).

23 See Hancock, Three Dimensions in 2( $f)$ Evidence in the Patent Office, 45 TradE-MARK REP. 1157 (1955). 
the requirement of proof should not impose an unreasonable burden upon an applicant..$^{24}$

It has for years been common busmess practice to adopt and use as trademarks descriptive terms (which are not the name of the goods or in common use by others to describe similar goods), surnames and geographical names. The courts have for years recognized a user's rights in such marks when they had acquired a secondary meaning. In 1946, Congress recognized such rights by making the marks registrable; and the Patent Office follows a rather liberal policy of authorizing registration when the facts support a finding of secondary meaning.

\section{Registrations Based on Concurrent Use}

One of the knottiest problems which confronts the administrators of the trademark registration statute is the proviso of subsection $2(\mathrm{~d})^{25}$ which deals with the issuance of registrations of the same or similar marks for the same or similar goods under prescribed conditions and limitations. The legislative history of the provision indicates that it was the intent of the framers and of Congress to permit the Patent Office to recognize those extraordimary circumstances where two users have used their respective marks over a sufficient period of time, whether in restricted territories ${ }^{26}$ or otherwise, and have invested in them to sucl an extent that a court, exercising its equity powers, would not interfere with continued use in the future.

For example, in the "White House"27 case and in the "Chipso"28 case the court refused to interfere with continued use of the marks by the defendants largely because of the hardship which would necessarily result. The defendants could not, however, under the interpretations of the 1905 act, obtain registration. The proviso of subsection 2 (d) was intended to correct the situation and permit registration of such marks as miglit be continued in use. It is possible for the Patent Office to issue such registrations either on the basis of its own findings in a proper case or on the basis of the findings of a court of competent jurisdiction.

There is no question but that the statutory provision was intended to provide an extraordinary remedy for extraordinary circumstances, ${ }^{20}$ and that it was not intended to be administered in such a manner as to under-

24 In re Hollywood Brands, Inc., 41 C.C.P.A. (Patents) 1001, 214 F.2d 139 (1954).

2560 STAT. 428 (1946), 15 U.S.C. $\$ 1052$ (d) (1952).

26 Hanover Star Milling Co. v. Metcalf, 240 U.S. 403 (1916).

27 Dwinell-Wright Co. v. White House Milk Co., 132 F.2d 822 (2d Cir. 1943).

28 Procter \& Gamble Co. v. J. L. Prescott Co., 102 F.2d 773 (3d Cir. 1939), cert. denied, 308 U.S. 557 (1939).

${ }^{29}$ Ex parte Chadbourn Hosiery Mills, Inc., 107 U.S.P.Q. 12, 45 TRADE-MARK REP. 1386 (Comm'r 1955). 
mine either the American concept of trademarks or the public's confidence in them. Unfortunately, the proviso of the subsection is too frequently seized upon as a means to attempt settlement of an ordinary controversy, and the parties agree that registrations may issue to both. This situation has caused to be evolved an administrative procedure which, it is believed, will serve the purpose of the statute, preserve the concept, and protect the public from confusion, mistake and deception.

Registration proceedings based on concurrent lawful use, whether territorially himited or otherwise, will be instituted only if, on the basis of facts presented ex parte by each of the parties involved, it appears to the satisfaction of the Patent Office that the mark of each party is actually a registrable mark, each party has substantial riglits as a result of what he has done, and on the basis of such facts, it is concluded that the territories are not likely to meet or that the public mind is probably "conditioned" by past circumstances to the extent that confusion, mistake or deception is not likely. In the absence of such a conclusion by the examiner in the first instance, concurrent use proceedings will not be instituted..$^{30}$

Mere consent of the parties to registration and agreements that confusion, mistake, or deception are unlikely are not sufficient to relieve the Patent Office of its responsibility of determining that: (1) the subject matter sought to be registered is registrable as a mark; (2) each party has substantial rights which are entitled to recognition by registration; and (3) confusion, mistake or deception probably will not occur.

Once these determinations are made and the concurrent use proceeding is instituted, it must proceed with a presentation of facts in the same manner and to the same extent as in any other adversary proceeding, on the basis of which it must be found that the adoption was bona fide and the use was lawful; substantial equities exist in both parties, as a result of what has occurred in the past; confusion, mistake or deception is unlikely; and a court in the exercise of its equity powers would not be likely to interfere with continued use of the marks by the parties on the goods specified.

Applications based on court decrees present no problem, since, if a court has already made the determination after hearing on the merits that there was lawful use by the defendant, substantial equities exist in both parties, confusion, mistake or deception is unlikely, and it will not interfere with continued use, the Patent Office will on the basis of a clear and unequivocal decree authorize publication of the mark or marks sought to be registered without the institution of concurrent use proceedings and without further inquiry.

If it will be borne in mind that concurrent use proceedings contemplate extraordinary circumstances and not a means for resolving ordinary con-

30 Ex parte M. Wile \& Co., 109 U.S.P.Q. 114, 46 Trademark ReP. 657 (Comm'r 1956). 
troversies, administration of that provision of the statute will be considerably simplified.

\section{Registrability of Service, Collective, and Certification Marks}

For a long time before the Act of 1946 became the law, it was widely recognized that trademarks for services represented valuable property rights just as did trademarks for goods, but the 1905 statute was limited to marks used on "merchandise" so far as registration was concerned. Generally speaking, there is very hittle difference between trademarks for services and trademarks for goods. In the administration of the registration provisions dealing with service marks, however, innumerable, though not insurmountable, problems have arisen-not from consideration of the marks, but from consideration of the services rendered. It would seem that service organizations, like producers of goods, have a common, usual or ordinary name by which they can identify their services so as to let the Patent Office know just what it is they are doing. For example, there are insurance underwriting, insurance brokerage, banking, railroad transportation, moving and transfer, real estate brokerage, advertising agency and the like. It is this common, usual or ordinary identification of the service which should be recited in the application to register; but instead, a great percentage of the applications contain long, involved descriptions which make it difficult, if not impossible, for one unfamiliar with the operations of the applicant to know what service is being performed. Such descriptions result in unnecessary delays in prosecution which might well be avoided if the services were identified by answering the following questions: (1) What is the applicant's business? (This must have a commonly used name.) (2) In what phase of that business is the mark used? This is a simple recommendation, but its use will provide proper identification in the great majority of cases.

The other major problem in connection with registration of service marks arises from the apparent desire of businessmen engaged in selling goods to obtain registration for all sorts of things which they call services, but which are merely incidental to the sale of their products. A reading of section $3^{31}$ and the definitions of "service mark" and "use" in section $45^{32}$ indicates clearly that it was the primary intent of the Congress to provide for registration by service organizations of their identifying marks used in connection with the performance of their services in interstate commerce. It was not the intent to make registrable names or pseudonyms of individuals used to identify such individuals, nor was it the intent to make registrable terms or coinbinations of words used in connection with the ordinary

3160 STAT. 429 (1946), 15 U.S.C. § 1053 (1952).

3260 STAT. $443-44$ (1946), 15 U.S.C. $\$ 1127$ (1952). 
and expected handling or sales promotion of one's own goods. The test for determining registrability in such cases is: ${ }^{33}$

A mark used by a person on or in connection with services normally ex-
pected of him and rendered merely as an accessory to and solely in further-
ance of the sale, offermg for sale, or distribution of his goods is not a service
mark within the purview of the Act; but a manufacturer, seller or distrib-
utor of goods who supplies a bona fide service or services over and above
those normally expected and only incidentally related to the furtherance
of such manufacture, sale or distribution is entitled to have the registrabil-
ity of his mark judged by the standards ordinarily applied in determining
registrability-whether the mark used to identify the service is the same as
or different from that used to identify the goods.

Titles of radio and television programs are service marks and are registrable as such, whether or not they advertise the products of the sponsor; and they are registrable by the person who owns the property in the identifying title.

Much of the difficulty with registration of service marks will disappear when applicants and their counsel recognize them for what they aretrademarks used to identify and distinguish services rendered as differentiated from trademarks used to identify and distinguish products.

Collective marks are of two types: (1) marks used by the members of a collective group to identify and distinguish the products sold or services performed by the members of such collective groups; and (2) marks which do not identify or distinguish products or services, but merely mdicate membership in an orgamzation which operates interstate or internationally.

In the first category fall the farm and dairy cooperative marks which often are mistakenly categorized as marks used by related companies. In the case of such cooperatives, quality control is exercised, but the marks exist as a result of $u s e$ by the members rather than as a result of any relationship contemplated by the related companies provisions of the statute. Registration should, therefore, be sought in such cases for collective marks.

The "membership marks" fall in a different category. They do not, in fact, identify anything other than the organization and its members. Such marks are: Greek letter fraternity marks, the Masonic emblem, the Boy Scouts of America emblems, the Rotary International emblem, etc. It is true that by nature they are a kind of hybrid, but they nevertheless perform a function of identification and as such are registrable. ${ }^{34}$

Certification marks are even more hybrid in nature. They do not identify anything, but they merely signify that someone other than the producer and seller of the goods has examined them in some mamier and certifies that 1953).

33 Ex parte Handmacher-Vogel, Inc., 98 U.S.P.Q. 413, 44 TRADE-Mark REP. 191 (Comm'r

34 Ex parte Supreme Order White Shrine of Jerusalem, 109 U.S.P.Q. 248 (Coinm'r 1956). 
they meet certain standards laid down by the certifier. Because of their nature and of the fact that a certifier does not ordinarily limit his certification to goods or services in a single class, it is permissible under the revised rules to state in the application that the mark is used in connection with "goods" or "services," as the case may be, without naming the specific goods or services. It is necessary, however, that the application state clearly what it is that the mark certifies.

Business practices developed these types of marks which, by and large, were non-existent in 1905; the courts protected them; but they were unregistrable under the terms of the statute. Congress revised the statute so that protectable rights may now be recognized by registration.

\section{Assignment of Part of the Business}

The final "modermization" to be mentioned in this paper is the section dealing with assignments. In 1905 when busmesses more often than not had one product or a line of closely related products sold under one mark, it seemed satisfactory to provide that a trademark shall be assignable with the goodwill of the business in which the mark is used ${ }^{35}$ As business operations expanded, however, and new marks were adopted for new products, it was impracticable in many instances to assign the goodrwill of the business when one of many marks was transferred. Strict interpretation of the statute would have required assignment of the whole business with one of many marks used in the business, although the courts were loath to construe it so strictly.

Here again, busmess practices led the way, and im 1946 Congress enacted legislation specifically authorizing assignment with that part of the goodwill connected with the use of and symbolized by the mark, adding that in any such assignment it shall not be necessary to include the goodwill connected with the use of and symbolized by any other mark used in the business or symbolized by the name or trade style under which the business is conducted. In other words, a business may now purchase one of a number of marks from someone else, and the seller may continue to operate at the same old stand under the same old name and sell its products identified by its other marks without fear of having the assignment declared invalid.

There is no question but that this is a legitimate busmess practice, and the practice is now recognized by statute, by the courts and by the Patent Office.

\section{CONSTRUCTIONS REMEDIED BY THE LANHAM ACT}

As the congressional committees stated, one purpose of the legislation was to remedy constructions of the prior acts which had in several instances

3533 STAT. 727 (1905), 15 U.S.C. $\$ 90$ (1952). 
obscured and perverted their original purpose. There were several of these constructions, but only the one considered to be of major importance will be treated here.

Section 13 of the Act of 1905 stated that "whenever any person shall deem himself injured by the registration of a trademark in the Patent Office he may at any time apply to the Commissioner of Patents to cancel the registration thereof." ${ }^{36}$ Three hittle words - "at any time"-were the source of the difficulty. The Patent Office and the Court of Customs and Patent Appeals consistently construed this phrase to mean that the petition could be filed at any time, and that these words in the statute precluded any equitable defense. ${ }^{37}$ To illustrate, the construction meant that a petition to cancel could be filed twenty-five years after a registration had issued, millions of dollars could have been invested in the mark and a substantial market created while the petitioner sat idly by, yet the case would be decided without regard to these facts, and likelihood of confusion would be determined in the same manner as if there were no facts presented at all. In fact, when one cancelation proceeding, filed nearly twenty years after issuance of the registration, came before the court on appeal from the Patent Office, the court said: ${ }^{38}$

While it seems strange that appellee, under the circumstances herein, has suddenly deemed itself injured, this, of course, cannot be considered by this court. Appellee, in the purely statutory proceeding provided for in said section 13, supra, had the right whenever it deemed itself injured by the registration of appellant's trademark, to file its petition for cancelation at any time....

It should be pointed out that following this decision the district court refused to interfere with continued use of the mark, and the decision was affirmed by the court of appeals. ${ }^{39}$

The result of such a construction was a wide divergence between the right to register and the right to use, which seemed imconsistent with the concept that use creates rights of ownership, and an owner may register his trademark.

Congress wrote into the statute three provisions designed to correct such a construction and to eliminate, at least in part, the inconsistency. First, it provided that registration is constructive notice of the registrant's claim of ownership; ${ }^{40}$ second, a petition to cancel must be filed within five

3633 Stat. 728 (1905), 15 U.S.C. $\$ 93$ (1952).

37 Cluett, Peabody \& Co, v. Hartogensis, 17 C.C.P.A. (Patents) 1166, 41 F.2d 94 (1930).

38 White House Milk Products Co. v. Dwinell-Wright Co., 27 C.C.P.A. (Patents) 1194, 1197, 111 F.2d 490, 493 (1940). See also Procter \& Gamble Co. v. J. L. Prescott Co., 22 C.C.P.A. (Patents) 1173, 77 F.2d 98 (1935).

39 Dwinell-Wright Co. v. White House, 44 F. Supp. 423 (W.D.N.Y. 1942), aff'd, 132 F.2d 822 (2d Cir. 1943).

4060 Stat. 435 (1946), 15 U.S.C. $\$ 1072$ (1952). 
years after the date of registration, except on specified grounds which affect the rights themselves; ${ }^{41}$ and third, equitable principles may be considered and applied. ${ }^{42}$

These provisions have been given effect by the tribunals of the Patent Office and by the Court of Customs and Patent Appeals ${ }^{43}$ with the ultimate result, it is to be hoped, that except in extraordinary cases the right to register will be coextensive with the right to use. ${ }^{44}$

\section{SIMPIIFICATION OF TRADEMARK PRACTICE}

One of the stated purposes of the act was to simplify trademark practice. The revision of rules effective August 15, 1955 was desigued largely to accomplish that purpose, and expediting policies now in effect have furthered it. A brief rundown of the major changes should be sufficient to show what the simplifications are.

Simple forms embodying all statutory requirements have been made available in the interest of conserving time in preparation, time in examining and time in prosecution.

Drawings of word or numeral marks may be typed on bond paper instead of drawn in India ink on bristol board..$^{45}$

In conformity with the International Convention for the Protection of Industrial Property, dates of first use and specimens showing the mark are no longer required of foreign applicants who have a registration in their home countries. ${ }^{46}$

Applications are examined for substance and not for form, and actions have been shortened and simplified.

Classification of goods is being administered more flexibly and realistically.

Interferences with registrations will be instituted only on specific authorization of the Commissioner ${ }^{47}$ and they are authorized only in extraordinary circumstances.

Issues in interferences between applications may be enlarged so as to provide an opportunity to obtain the facts upon which the rights of the

4160 STAT. 433 (1946), 15 U.S.C. § 1063 (1952).

4260 STAT. 434 (1946), 15 U.S.C. \$ 1069 (1952).

43 Salem Commodities Inc. v. Miami Margarine Co., 106 U.S.P.Q. 411, 45 TradE-MARK Rep. 1389 (Comm'r 1955); In re Myers, 40 C.C.P.A. (Patents) 747, 201 F.2d 379 (1953); Flintkote Co. v. Merriam \& Co., 88 U.S.P.Q. 390, 41 Trade-MARK REp. 358 (Chief Exam'r 1951).

44 Squirrel Brand Co. v. Barnard Nut Co., 101 U.S.P.Q. 340, 44 Trade-MaRK ReP. 1114 (Comm'r 1954).

4537 C.F.R. § 2.51(d) (Supp. 1955). See note 9 supra.

4637 C.F.R. \& 2.39 (Supp. 1955).

${ }^{47} I d . \S 2.91(\mathrm{c})$. 
parties may be established, rather than limiting the determination merely to first use. ${ }^{48}$

Affirmative defenses are available in all litigation in the Patent Office. ${ }^{49}$

Limited discovery procedure, tailored to the peculiarities of practice without interlocutory learings, has been made available. ${ }^{50}$

Patent Office records are in evidence when pleaded. ${ }^{51}$

Copies of testimony and exhibits are required to be served on adverse parties before their trial period. ${ }^{52}$

Oral hearings before the lower tribunal of the Office must be requested at the time the brief is filed, ${ }^{53}$ thereby conserving time of Office personnel and serving to notify the adverse party of intended appearance.

Motions to dismiss are provided for in cases where the party in position of plaintiff fails to offer any evidence other than Patent Office records. ${ }^{54}$

The appeal period in ex parte refusals has been shortened from six months to sixty days, thereby expediting final termination. ${ }^{55}$

Petitions for review of interlocutory matters are made available. ${ }^{56}$

These are the hightights of the revision which envisaged simplification of practice and expedition of prosecution of trademark cases in the Patent Office. Basically, the rules are designed to provide an orderly procedure for presenting facts in order that a final determination may be made as to registrability to the end that all marks in lawful use in interstate, foreign, or Territorial commerce may be registered. In contested cases, particularly, facts are essential to evaluate properly the probable effect on purchasers and potential purchasers of the involved marks as they appear on the products in the usual markets. As Mr. Justice Frankfurter so aptly put it, "The protection of trademarks is the law's recognition of the psychological function of symbols;" only on a fact basis.

\section{CONCLUSION}

From the viewpoint of the government agency which administers the Lanham Act, so far as its registration provisions are concerned, the act provides a flexible base upon which recognition of trademark rights by reg-

$48 I d . \S 2.97$.

$49 I d . \S \S 2.106,2.114$.

s0 Id. $\S 2.120$.

51 Id. \$ 2.122 .

52 Id. \$ 2.125.

53 Id. § 2.128(c).

54 Id. $\$ 2.132$ (b).

55 Id. $\$ 2.142$ (a).

$56 I d . \$ 2.146$.

57 Mishawaka Rubber \& Woolen Mfg. Co. v. S. S. Kresge Co., 316 U.S. 203, 205 (1942). See Leeds, Confusion and Consumer Psychology, 46 TrademaRK REP. 1 (1956). 
istration may be granted. By avoiding rigid rules of measurement and evaluating each mark in its factual setting, the purposes so clearly stated by the congressional committees and the expressed intent of the legislation, as set forth in the statute,,$^{58}$ will be realized.

6860 STAT. 443 (1946), 15 U.S.C. § 1127 (1952). 